\title{
High arsenic levels in groundwater resources of Gediz Graben, Western Turkey
}

\author{
Alper Baba \\ İzmir Institute of Technology, Izmir, Turkey
}

Orhan Gündüz, Celalettin Şimşek, Alper Elçi, Hasan Sözbilir

Dokuz Eylul University, Izmir, Turkey

Alim Murathan

SUMMARY: Gediz Graben situated in western Turkey is an area containing extensional structures with active tectonics and geothermal systems that serves as a suitable environment for the presence of high levels of arsenic in groundwater. The results of a comprehensive monitoring program in the basin revealed that the maximum arsenic concentration detected during the monitoring program was $3086 \mathrm{ppb}$ and the average value was calculated to be $23.63 \mathrm{ppb}$. In addition, arsenic levels in $28 \%$ of the water samples were above the $10 \mathrm{ppb}$ limit value making them unsuitable for drinking water supply. These high arsenic concentrations in the basin was mostly associated with long detention times of water in altered rocks located along detachment faults, strong water-rock interaction processes in the alteration zones and anthropogenic influences made within the geothermal fluid reservoir.

\section{INTRODUCTION}

Occurrence of arsenic in groundwater has been a major problem worldwide since the last century. Arsenic related problems have been encountered recently in several countries including Bangladesh, India, Indonesia, Nepal, Myanmar, Mexico Pakistan, Vietnam, Cambodia, China (Mukherjee et al., 2006) and Turkey (Baba and Gündüz, 2010). It is estimated that nearly 125-150 million people are exposed to the potential risk of arsenic toxicity (Bhattacharya et al., 2002). Recently, arsenic pollution is becoming a major topic in the agenda of Turkey as well. Particularly, high arsenic levels have been detected in water resources flowing through volcanic rocks in western part of Turkey such as Afyon, Çanakkale, Isparta, Kütahya, Manisa, Muğla and Izmir (Gündüz et al., 2010). In many of these locations, arsenic is naturally found in the subsurface strata within volcanic, metamorphic and sedimentary formations as well as in areas of geothermal systems related to tectonic activity. Based on this background, this study focuses on high arsenic levels in groundwater resources of the Gediz Graben located in western Turkey, which is one such area of complex geology with active tectonics and high geothermal potential.

\section{GEOLOGY OF STUDY AREA}

The Gediz Graben is $140 \mathrm{~km}$ long and 3-40 km wide and has a WNW-ESE trending structure bounded by active normal faults (Fig. 1). The Gediz detachment fault is one of several crustal-scale detachment faults that forms the southern margin of the Gediz Graben (Sözbilir 2001; Sözbilir, 2002).
Many geothermal fields (i.e., Turgutlu (Urganl1), Salihli and Alaşehir) are present along the Gediz Graben with measured reservoir temperatures reaching as high as $287^{\circ} \mathrm{C}$.

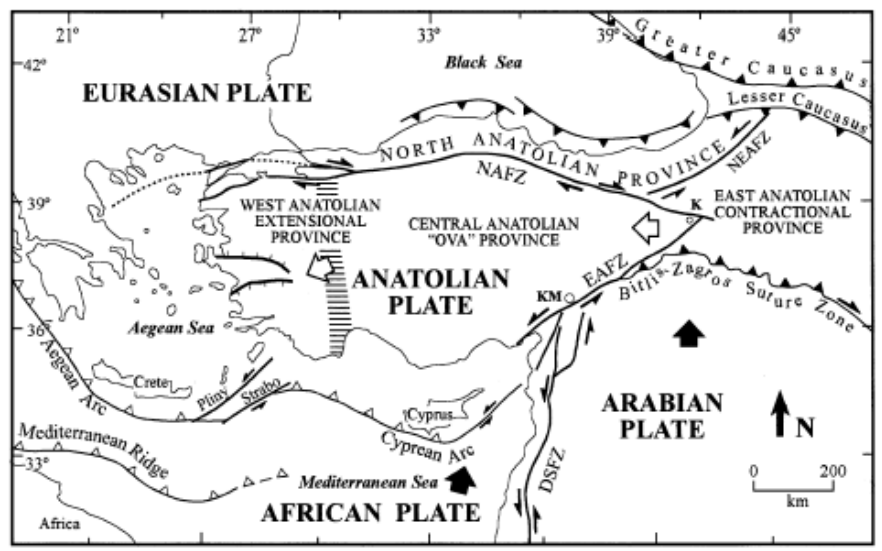

Fig. 1. Simplified tectonic map of Turkey showing major neotectonic structures and neotectonic provinces (from Barka, 1992; Bozkurt, 2001).

Based on the tectonic characteristics and the geological structure of Gediz Graben, wells drilled in arsenic containing geological formations and boreholes that are close to geothermal resources are likely to contain high arsenic levels. Majority of these wells cut hydrothermally altered and fractured metamorphic and sedimentary rocks due to the influence of active faults. These rocks are characterized by phyllic, argillic, and silicic-hematitic alteration zones in Gediz Graben (Baba, 2010; Gündüz et al., 2010; Baba and Sözbilir, 2012). Especially along the detachment fault, there are wide areas of alteration with mineral assemblages that range from advanced argillic type through silicification to deeper level propylitization. Such areas are also enriched by arsenic. 


\section{METHODS}

A comprehensive water quality monitoring program with three sampling campaigns and a total of 750 groundwater quality monitoring stations was conducted in the Gediz River Basin during the wet and dry seasons of 2013-2014. About $60 \%$ of these stations were situated within the Gediz Graben area. Arsenic samples were collected into $50 \mathrm{~mL}$ plastic bottles and were later acidified with $0.5 \mathrm{~N} \mathrm{HNO}_{3}$ to prevent the complex formation. In the laboratory, samples were filtered through $0.45 \mu \mathrm{m}$ filter paper and measured with ICP-MS.

\section{SOURCE OF ARSENIC IN GEDİZ GRABEN}

Arsenic in the basin was found to be above the 10 ppb limit value in $28 \%$ of the water samples. High concentrations of arsenic were observed in all parts of the basin but particularly in deep wells in the central portions of the graben area (Figure 2). These locations are located around the geothermal fields and within alteration zones. The maximum arsenic concentration detected during the monitoring program was $3086 \mathrm{ppb}$ whereas the average value was calculated to be $23.6 \mathrm{ppb}$ with a standard deviation value of $131.5 \mathrm{ppb}$.

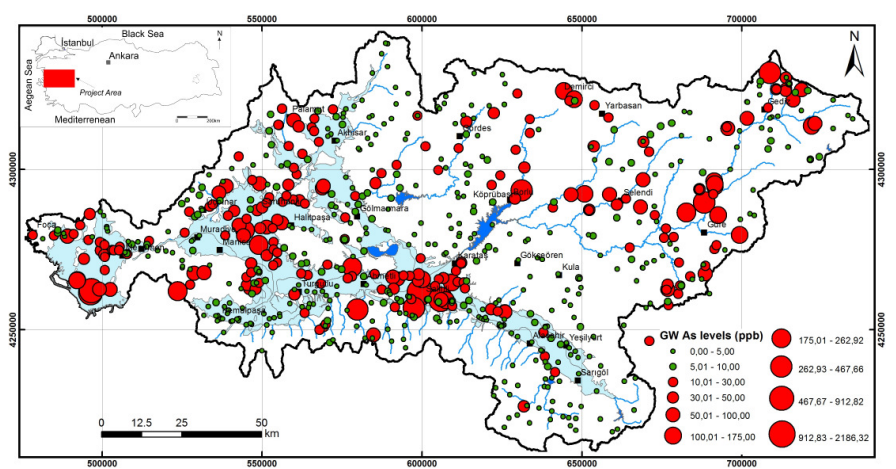

Fig. 2. Distribution of groundwater arsenic in Gediz River Ba$\sin$

The analysis revealed that arsenic in the basin exceeded $10 \mathrm{ppb}$ limit value for drinking water quality and the majority of water supply wells were not suitable for human consumption. The hydrogeochemical assessment in the basin also revealed that the main reason for obtaining high arsenic concentrations in the basin was associated with the long detention times of water in altered rocks located along the detachment faults and strong water-rock interaction processes in these alteration zones as well as the strong anthropogenic influences within the geothermal fluid reservoir.

\section{CONCLUSIONS}

Due to its active extensional tectonics and presence of rich geothermal resources, Gediz Graben contains various altered rock that contain elevated levels of arsenic. Dissolution from these rocks are mostly responsible for the elevated arsenic concentrations in groundwater that exceed the maximum allowable limits for drinking water. Thus, it is important to continuously monitor arsenic in the basin and to introduce arsenic removal practices for all residential areas in Gediz Graben that depend on local groundwater.

\section{ACKNOWLEDGEMENTS}

The authors acknowledge the support of State Hydraulic Works (DSİ) on this study.

\section{REFERENCES}

Baba, A. 2010. High arsenic levels in water resources resulting from alteration zones: a case study from Biga Peninsula, Turkey. Proceedings of AS2010: The Third International Congress on Arsenic in the Environment, 17-21 May, 2010, Taiwan

Baba, A., Gündüz, O. 2010. Effect of alteration zones on water quality: A Case Study from Biga Peninsula, Turkey, Archives of Environmental Contamination and Toxicology, 58(3):499-513

Baba, A., Sözbilir, H. 2012. Source of Arsenic Based on Geological and Hydrogeochemical Properties of Geothermal Systems in Western Turkey, Chemical Geology, 334:364-377.

Barka A.A. 1992. The North Anatolian Fault zone. Annales Tecton. 6, 164-195.

Bhattacharya, P., Frisbie, S.H., Smith, E., et al. 2002. Arsenic in the Environment: A Global Perspective. In: Sarkar B (ed) Handbook of Heavy Metals in the Environment: Marcell Dekker Inc., New York, pp. 145-215.

Bozkurt, E., 2001. Neotectonics of Turkey-a synthesis. Geodinamica Acta 14:3-30.

Gündüz, O., Baba, A., Elpit, H. 2010. Arsenic in groundwater in Western Anatolia, Turkey: a review. XXVIII IAH Congress, Groundwater Quality Sustainability, 12-17 September 2010, Krakow, Poland, pp. 183-191

Mukherjee, A, Sengupta, M.K., Hossain, M.A., et al. 2006. Arsenic contamination in groundwater: a global perspective with emphasis on the Asian scenario, J Health Popul Nutr, 24(2):142-63.

Sözbilir, H. 2001. Extensional tectonics and the geometry of related macroscopic structures: field evidence from the Gediz detachment, western Turkey. Turkish Journal of Earth Sciences 10:51-67.

Sözbilir, H. 2002. Geometry and origin of folding in the Neogene sediments of the Gediz Graben, western Anatolia, Turkey. Geodinamica Acta 15:277-288. 